\title{
Active layer thermal monitoring of a Dry Valley of the Ellsworth Mountains, Continental Antarctica
}

\author{
Carlos Ernesto G.R. Schaefer ${ }^{\text {a }}$, Roberto F.M. Michel ${ }^{\text {b,* }}$, Caroline Delpupo a , Eduardo O. Senra ${ }^{\text {a }}$, \\ Ulisses F. Bremer ${ }^{c}$, James G. Bockheim ${ }^{\mathrm{d}}$ \\ a Departamento de Solos, Universidade Federal de Viçosa, Viçosa, Brazil \\ b Departamento de Ciências Agrárias e Ambientais, Universidade Estadual de Santa Cruz, Ilhéus, Brazil \\ c Instituto de Geociências, Universidade Federal do Rio Grande do Sul, Porto Alegre, Brazil \\ ${ }^{\mathrm{d}}$ Department of Soil Science, University of Wisconsin, Madison, United States
}

\section{A R T I C L E I N F O}

\section{Article history:}

Received 15 November 2015

Received in revised form 13 July 2016

Accepted 14 July 2016

Available online 26 July 2016

\section{Keywords:}

Active layer

Dry Valley

Ellsworth Mountains

Continental Antarctica

\begin{abstract}
A B S T R A C T
The Ellsworth Mountains are located along the southern edge of the Ronne-Filchner Ice Shelf and are subdivided by the Minnesota Glacier into the Heritage Range to the east, and the Sentinel Range to the west (Figure 1). The climate of the Ellsworth Mountains is strongly controlled by proximity to the Ronne-Filchner Ice Shelf and elevation. The entire ice free area is underlain by continuous permafrost of unknown thickness, most in the form of dry permafrost. Active-layer depths in drift sheets of the Ellsworth Mountains range from 15 to $50 \mathrm{~cm}$. Detailed knowledge on Antarctic permafrost is patchy, especially at the continent. Two adjacent active layer monitoring sites were installed at Mt. Dolence, Ellsworth Mountains, in the summer of 2012. Two dry-valley soils at Mt. Dolence area, on quartzite drift deposits were studied: (i) a convex-slope site exposed to the wind (Lithic Haplorthel $886 \mathrm{~m}$ asl, $5 \mathrm{~cm}, 10 \mathrm{~cm}, 30 \mathrm{~cm}$ ); and a sheltered concave-slope site protected from winds (Lithic Anhyorthel $850 \mathrm{~m}$ asl, $5 \mathrm{~cm}, 10 \mathrm{~cm}, 30 \mathrm{~cm}$ ). Data was recorded at hourly intervals from January 2nd 2012 until December 29th 2013. The soil climate temperature at $5 \mathrm{~cm}$ reaches a maximum daily mean in late December, reaching a minimum in mid July at both sites. Active layer thickness reaches a maximum of $48.4 \mathrm{~cm}$ at P1 on January 17th 2013 and $47.8 \mathrm{~cm}$ at P2 on January 7th 2012. The soil thermal regime at the dry valley of Mt. Dolence, Ellsworth Mountains is characteristic of cold desert affected by dry-frozen permafrost. Although air temperature does not reach elevated positive values, variations in soil temperature are intense, showing the soil's response to solar radiation. The origins of typical surface periglacial features and landform on the widespread Ellsworth drifts may be inherited from past events of warmer climates, since liquid water is unlikely to play any significant role under the present climate.
\end{abstract}

(C) 2016 Elsevier B.V. All rights reserved.

\section{Introduction}

The Ellsworth Mountains form a $360 \mathrm{~km}$ (224 mi) long and $48 \mathrm{~km}$ (30 mi) wide mountain range; they are divided by the Minnesota Glacier into the Heritage Range and the Sentinel Range. Discovered by Lincoln Ellsworth, during a trans-antarctic flight, they are aligned north to south on the western margin of the Ronne Ice Shelf, being considered the highest mountain range in Antarctica and the largest portion of ice-free area $\left(30,400 \mathrm{~km}^{2}\right)$.

Due to recent climate change trends, human effects on the active layer and permafrost have received increasing attention (Bockheim,

\footnotetext{
* Corresponding author.

E-mail addresses: carlos.schaefer@ufv.br (C.E.G.R. Schaefer), roberto@michel.com (R.F.M. Michel), caroldelpupo@yahoo.com.br (C. Delpupo), senra.eduardo@gmail.com (E.O. Senra), bremer@ufrgs.br (U.F. Bremer), bockheim@wisc.edu (J.G. Bockheim).
}

1993; Campbell et al., 1994). Realistically 25\% or less of the Antarctic region contains permafrost (Bockheim, 1995); much of the area under the eastern and western ice sheets is above the pressure melting point and remains unfrozen. The concept of an active layer is less meaningful in interior Antarctica, where soil moisture content is $<3 \%$ (Bockheim, 1995; Campbell et al., 1994; Black and Berg, 1963; Bockheim and Tarnocai, 1998). Therefore, much of the permafrost in interior Antarctica is 'dry' (Bockheim and Tarnocai, 1998; Bockheim, 2002).

A complete model describing the genesis of dry permafrost is yet to be achieved, though speculations point to materials deposited by drybased glaciers that undergo ice loss though sublimation over time, in a cold and arid environment (Bockheim and Tarnocai, 1998; Black and Berg, 1963; Ugolini, 1964; Ugolini and Bull, 1965). Dry permafrost occurs throughout the dry valleys of the Transantarctic Mountains in southern Victoria Land, especially at elevations below $900 \mathrm{~m}$ (Cameron, 1969). In some cases, ice-cemented permafrost exists 
below dry permafrost to depths approaching $1000 \mathrm{~m}$ (Cartwright et al., 1974; Decker and Bucher, 1977).

Active layer depths in drift sheets of the Ellsworth Mountains range from 15 to $50 \mathrm{~cm}$ and the entire area is underlaid by continuous permafrost of unknown thermal regime and thickness (Bockheim and Schaefer, 2015). Based on data collected from 22 pits, $41 \%$ of the sites contained dry permafrost below $70 \mathrm{~cm}, 27 \%$ had ice-cemented permafrost within $70 \mathrm{~cm}$ of the surface, $27 \%$ had bedrock within $70 \mathrm{~cm}$, and $5 \%$ contained an ice-core (Bockheim and Schaefer, 2015).

The shortage of information about dry permafrost is applicable to most of Antarctica, with the possible exception of the McMurdo Dry Valleys, where substantial research has taken place over the past several decades (Vieira et al., 2010). Elsewhere in Antarctica, permafrost research has been less systematic. Additionally, there has not been a coordinated effort to monitor permafrost properties and active-layer dynamics, except by individual countries and researchers, mostly in the vicinity of their research stations (Vieira et al., 2010). Such initiative is uncommon on remote continental areas such as the Ellsworth Mountains due to difficulties regarding installation and maintenance of the monitoring equipment.

This study is an essential part of the 'Antarctic and sub-Antarctic Permafrost, Periglacial and Soil Environments' (ANTPAS) project, coordinated by the International Permafrost Association and the Scientific Committee on Antarctic Research Expert Group on Permafrost and Periglacial Environments, aims at addressing key issues of Antarctic permafrost science.

The comprehension of the properties, thermal regime and distribution of Antarctic permafrost, including dry permafrost, is crucial to monitor and predict climate induced changes. Permafrost degradation affects the surface energy balance, snow cover, soil hydrologic properties and the effectiveness of the buffering action of the active layer. All which can lead to an increase in the mean summer surface temperature accompanied by deeper thawing of the active layer.

We studied the thermal regime of two contrasting sites with cold desert soil at the largest dry valley at Mt. Dolence, Ellsworth Mountains. The objective of this study is to contribute to the knowledge of the properties, thermal regime and distribution of Antarctic dry permafrost where no information on permafrost and active layer is available.

\section{Materials and methods}

\subsection{Regional setting}

The mean annual air temperature along the Transantarctic and Ellsworth Mountains, ranges from -15 to $-20{ }^{\circ} \mathrm{C}$ in coastal areas to $-35{ }^{\circ} \mathrm{C}$ along the polar plateau; the mean annual accumulation of water-equivalent precipitation likely ranges from 150 to $175 \mathrm{~mm}$ year $^{-1}$ (Bockheim and Schaefer, 2015). Elevation and the proximity to the surrounding ice shelf are the main variables controlling climate (Fig. 1). The vegetation cover is very rare, and restricted to a few lichen in the highest mountains (Øvstedal and Schaefer, 2013; Bockheim and Schaefer, 2015).

Geological formations include the Late Precambrian Minaret Group (marble), the middle to late Cambrian Heritage Group (sedimentary rocks), the upper Cambrian to Devonian Crashsite Group (predominantly quartzites), the Permo-Carboniferous Whiteout Conglomerate, and the Permian Polestar Formation (marine and terrestrial tillites) (Webers et al., 1992). At the study site, Mt. Dolence, quartzites prevail,
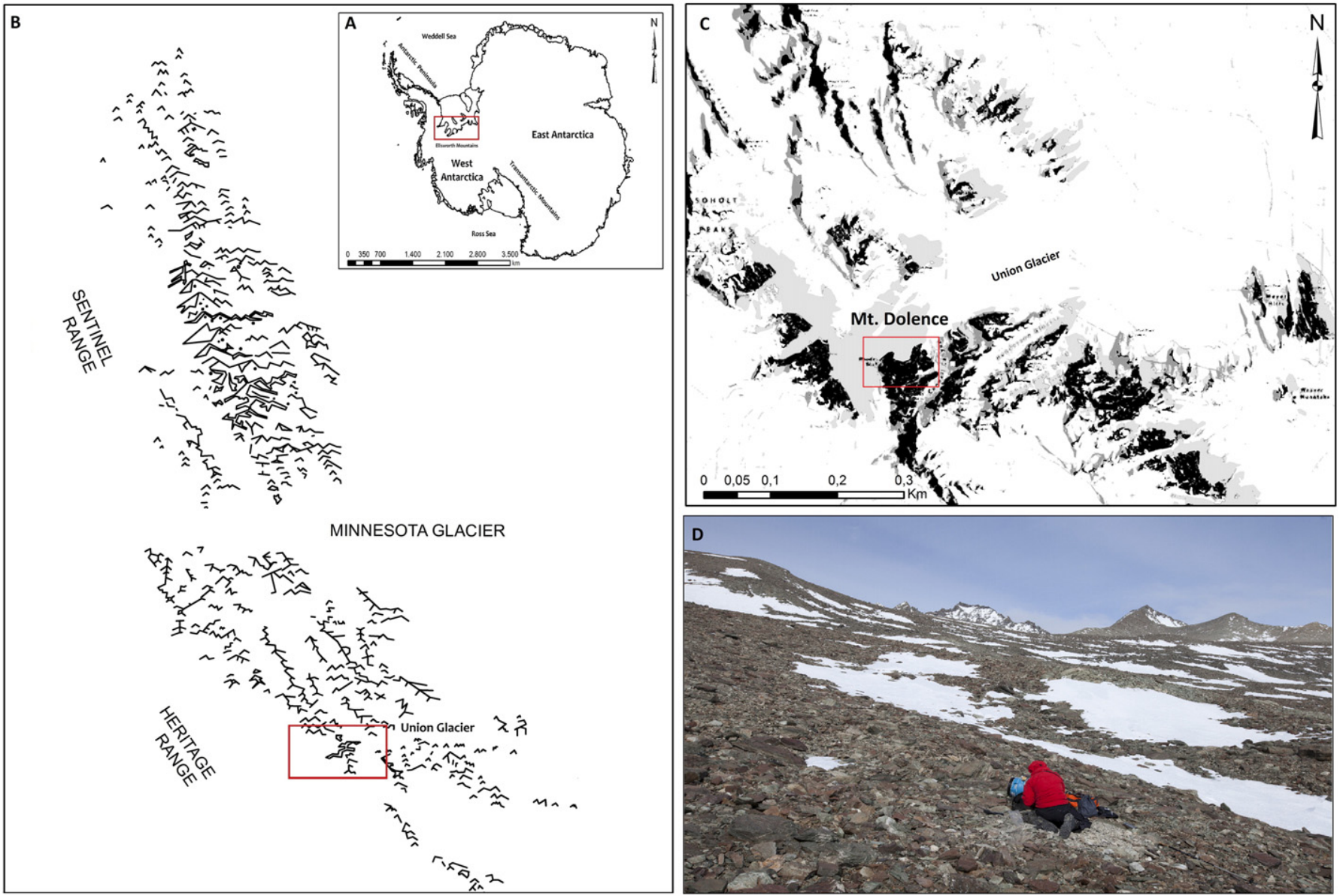

Fig. 1. Ellsworth Mountains in Antarctica context (A); Union Glacier area (B); Mt. Dolence area (C); Mt. Dolence, location of the monitored profiles (D). 


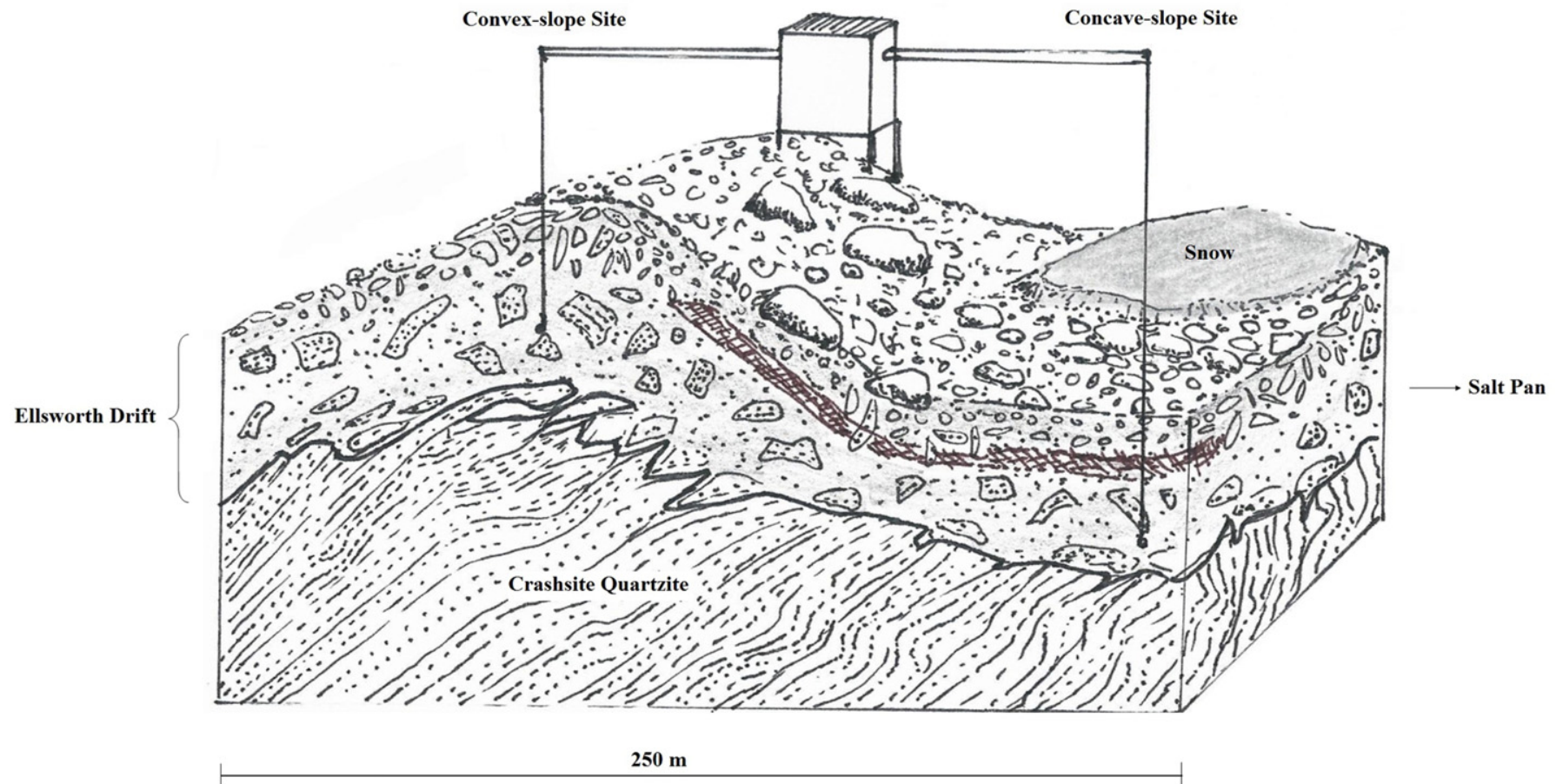

Fig. 2. Diagram of the studied site and regional setting of the monitored profiles.

together with occasional phyllites. Locally, a drift deposit covers bedrock with depth between 25 and $105 \mathrm{~cm}$.

Fieldwork was performed in 2012/2013, and soil pits were excavated to at least $100 \mathrm{~cm}$ depth to dry-frozen permafrost, ice or icecemented permafrost. The active layer (seasonal thaw) in the study areas varied between 15 and $50 \mathrm{~cm}$; material below this depth that is not cemented by ice contains dry-frozen permafrost.

\subsection{Methods}

Two adjacent active layer monitoring sites were installed at Mt. Dolence, Ellsworth Mountains ( $\left.79^{\circ} 49^{\prime} 18,5^{\prime \prime} \mathrm{S} / 83^{\circ} 11^{\prime} 49,7^{\prime \prime} \mathrm{W}\right)$, in the summer of 2012 (Fig. 2). Two dry-valley soils on quartzite drift deposits were studied: (i) a convex-slope site with wind exposed face (Lithic Haplorthel $886 \mathrm{~m}$ asl, $5 \mathrm{~cm}, 10 \mathrm{~cm}, 30 \mathrm{~cm}$ ); and a sheltered concave-slope site protected from winds (Lithic Anhyorthel $850 \mathrm{~m}$ asl, $5 \mathrm{~cm}, 10 \mathrm{~cm}, 30 \mathrm{~cm}$ ). They consist of thermistors (accuracy $\pm 0.2{ }^{\circ} \mathrm{C}$ ) (model 107 Temperature Probe, Campbell Scientific Inc., Utah, USA) arranged in a vertical array, installed directly in the soil profile at different depths. One sensor was installed at $1 \mathrm{~m}$ above ground for air temperature measurements (protected by a radiation shield). Data is considered $20 \mathrm{~h}$ after installation allowing the profile to cool, all probes were connected to a data logger (model CR 1000, Campbell Scientific Inc., Utah,
USA) recording data at hourly intervals from January 2nd 2012 until December 29th 2013 (728 days), January 1st 2012, December 30th and 31 st are not considered in yearly statistics, treated as no data.

The characteristics of the monitored sites and the exact depth of the probes are presented in Tables 1 and 2. We calculated the thawing days (days in which all hourly soil temperature measurements are positive and at least one reading is warmer than $0.5^{\circ} \mathrm{C}$ ), freezing days (days in which all hourly soil temperature measurements are negative and at least one reading is colder than $-0.5^{\circ} \mathrm{C}$ ), isothermal days (days in which all the hourly measurements range only between $\pm 0.5^{\circ} \mathrm{C}$ ), freeze-thaw days (days in which there are both negative and positive temperatures with at least one value higher than $0.5^{\circ} \mathrm{C}$ or lower than $-0.5^{\circ} \mathrm{C}$ ), thawing degree days (TDD, obtained by the cumulative sum of the mean daily temperatures above $0{ }^{\circ} \mathrm{C}$ ) and freezing degree days (FDD, obtained by the cumulative sum of the mean daily temperatures below $0{ }^{\circ} \mathrm{C}$ ) according to Guglielmin et al. (2008). The active-layer thickness (ALT) was calculated as the $0{ }^{\circ} \mathrm{C}$ depth by extrapolating the thermal gradient from the two deepest temperature measurements (Guglielmin, 2006). A freezing "n-factor" (FNF) (Kane et al., 2001) was calculated considering the ratio of the sum of freezing degree days at the $5 \mathrm{~cm}$ soil layer to that in the air for each month (usually the n-factor is defined as the ratio of the sum of thawing degree days at the soilsurface to that in the air).

Table 1

General characteristics of the monitored site.

\begin{tabular}{|c|c|c|c|c|c|}
\hline Site & Altitude & Soil class Soil taxonomy & Lat./Long. & $\mathrm{ALT}^{\mathrm{a}}$ & Thermistor depth \\
\hline P1 & $886 \mathrm{~m}$ & Lithic Haplorthel & $79^{\circ} 49^{\prime} 18,5^{\prime \prime} \mathrm{S} / 83^{\circ} 11^{\prime} 49,7^{\prime \prime} \mathrm{W}$ & $48.4 \mathrm{~cm}$ & $\begin{array}{l}5 \mathrm{~cm} \\
10 \mathrm{~cm} \\
30 \mathrm{~cm}\end{array}$ \\
\hline P2 & $850 \mathrm{~m}$ & Lithic Anhyorthel & $79^{\circ} 49^{\prime} 14,5^{\prime \prime} \mathrm{S} / 83^{\circ} 11^{\prime} 42,7^{\prime \prime} \mathrm{W}$ & $47.8 \mathrm{~cm}$ & $\begin{array}{l}5 \mathrm{~cm} \\
10 \mathrm{~cm} \\
30 \mathrm{~cm}\end{array}$ \\
\hline
\end{tabular}

\footnotetext{
a ALT - Active Layer Thickness.
} 
Table 2

Depth, color and texture of the soil horizons of the studied profiles.

\begin{tabular}{|c|c|c|c|c|c|c|c|c|}
\hline \multirow[b]{2}{*}{ Hor. } & \multirow[b]{2}{*}{ Depth $(\mathrm{cm})$} & \multirow[b]{2}{*}{ Color } & & $\mathrm{CS}^{*}$ & $\mathrm{FS}^{* *}$ & Silt & Clay & \multirow[b]{2}{*}{ Textural class } \\
\hline & & & & \multicolumn{4}{|c|}{$\mathrm{dag} \cdot \mathrm{kg}^{-1}$} & \\
\hline \multicolumn{9}{|l|}{$P 1$} \\
\hline $\mathrm{C} 1$ & $6-12$ & $5 Y 8 / 2$ & Pale yellow & 73 & 10 & 11 & 6 & Loamy-sand \\
\hline C2 & $12-20$ & $5 Y 8 / 1$ & White & 79 & 6 & 12 & 3 & Loamy-sand \\
\hline C3 & $20-25$ & $5 Y 8 / 1$ & White & 77 & 9 & 11 & 3 & Loamy-sand \\
\hline \multicolumn{9}{|l|}{ P2 } \\
\hline $\mathrm{C} 1$ & $0-6$ & $5 Y 7 / 2$ & Light gray & 75 & 12 & 10 & 3 & Loamy-sand \\
\hline C2 & $6-25$ & $5 Y 5 / 2$ & Light gray & 82 & 7 & 8 & 3 & Loamy-sand \\
\hline
\end{tabular}

${ }^{*} \mathrm{CS}=$ Coarse Sand $(2-0,2 \mathrm{~mm}),{ }^{* *} \mathrm{FS}=$ Fine Sand $(0,2-0,05 \mathrm{~mm})$, Silt $(0,05-0,002 \mathrm{~mm})$, Clay $(<0,002 \mathrm{~mm})$, dag $\cdot \mathrm{kg}^{-1}$, decagram per kilogram.

The apparent thermal diffusivity (ATD) was estimated for different seasons from the equation of McGaw et al. (1978):

$\alpha=[\Delta \mathrm{Z2} / 2 \Delta \mathrm{t}] \times[(\mathrm{Tij}+1-\mathrm{Tij}-1) /(\mathrm{Tji}-1-2 \mathrm{Tji}+\mathrm{Tji}+1)]$

where $\alpha=$ apparent thermal diffusivity $\left(\mathrm{m}^{2} \mathrm{~s}^{-1}\right), \Delta \mathrm{t}=$ time increments $(\mathrm{s}), \Delta \mathrm{Z}=$ space increments $(\mathrm{m}), \mathrm{T}=$ temperature, $\mathrm{j}=$ temporal position and $\mathrm{i}=$ depth position. Nelson et al. (1985), Outcalt and Hinkel (1989), Hinkel et al. $(1990,2001)$ have used this estimative to assess the resistance to energy flux in the profile. Hourly estimations were made for intermediate depths of both profiles, and mean values were calculated and plotted for each day.

A series of statistical analysis were performed to describe the soil temperature time series. The Box-Pierce test and augmented DickeyFuller tests were performed to confirm the stationarity and independent distribution of the time series (data not shown). The histogram (frequency distribution of temperature readings) and first difference (the difference between consecutive hourly temperature readings) were plotted, and the time series was decomposed into its seasonal and trend components by locally weighted smoothing (Loess) using a window of 25.

\section{Results}

Temperature at $5 \mathrm{~cm}$ reached a maximum daily mean in late December 2012, and a minimum in mid July 2013 on P1 $\left(10.9{ }^{\circ} \mathrm{C}\right.$, $\left.-37.9{ }^{\circ} \mathrm{C}, \pm 11.1{ }^{\circ} \mathrm{C}\right)$ and P2 $\left(6.9{ }^{\circ} \mathrm{C},-37.1^{\circ} \mathrm{C}, \pm 10.2{ }^{\circ} \mathrm{C}\right.$ ) (Table 3) (Fig. 3). The active layer thickness (ALT) reached a maximum of $48.4 \mathrm{~cm}$ at P1 on January 17th 2013 and $47.8 \mathrm{~cm}$ at P2 on January 7th 2012, as the $0{ }^{\circ} \mathrm{C}$ depth by extrapolating the thermal gradient from the two deepest temperature measurements (Guglielmin, 2006). Bockheim and McLeod (2008) found ALT ranging from 20 to $45 \mathrm{~cm}$ at xerous regions, such as central Taylor, Wright and Victoria Valleys; while subxerous areas, such as Marble Point, Walcott Bay and Granite Harbour, sustain deeper ALT, ranging from 45 to $70 \mathrm{~cm}$. Mckay et al. (1998) found the top of dry permafrost at $12.5 \mathrm{~cm}$ above the top of the ice-cemented permafrost $(25 \mathrm{~cm})$ at Linnaeus Terrace.

No isothermal day were recorded for the studied period; one thaw day was recorded at $5 \mathrm{~cm}$ on P2, 143 freeze thaw days were recorded at $5 \mathrm{~cm}, 81$ at $10 \mathrm{~cm}$ and 46 days at $30 \mathrm{~cm}$ on P1, on P2 118 FTD were recorded at $5 \mathrm{~cm}, 80$ at $10 \mathrm{~cm}$ and 42 days at $30 \mathrm{~cm}$. The majority of the days were classified as freeze days at both sites; 585 at $5 \mathrm{~cm}, 647$ at $10 \mathrm{~cm}$ and 684 days at $30 \mathrm{~cm}$ on P1, on P2 611 FD were recorded at $5 \mathrm{~cm}, 650$ at $10 \mathrm{~cm}$ and 688 days at $30 \mathrm{~cm}$. Only 17 FTD were recorded for air temperature and 713 FD (Fig. 4). Over the 728 days of the studied period the sum of all positive daily mean temperatures was 166.3 and $23.8^{\circ} \mathrm{C}$ day at 5 and $10 \mathrm{~cm}$ on P1, respectively; 45.0 and $5.2{ }^{\circ} \mathrm{C}$ day at 5 and $10 \mathrm{~cm}$ on $\mathrm{P} 2$, respectively. No positive daily mean were recorded at $30 \mathrm{~cm}$ at both sites. The sum of all negative daily mean temperatures was $-13,504.5{ }^{\circ} \mathrm{C}$ day at $5 \mathrm{~cm},-13,389.9{ }^{\circ} \mathrm{C}$ day at $10 \mathrm{~cm}$ and $-13,381.0{ }^{\circ} \mathrm{C}$ day at $30 \mathrm{~cm}$ on $\mathrm{P} 1,-13,508.0{ }^{\circ} \mathrm{C}$ day at $5 \mathrm{~cm}$, $-13,486.6{ }^{\circ} \mathrm{C}$ day at $10 \mathrm{~cm}$ and $-13,398.9{ }^{\circ} \mathrm{C}$ day at $30 \mathrm{~cm}$ on P2. Hrbáček et al. (2015) summed $849{ }^{\circ} \mathrm{C}$ day and $-5660{ }^{\circ} \mathrm{C}$ day at $5 \mathrm{~cm}$ in a two year experiment at a similar cold desert environment (James Ross Island, $63^{\circ} 52^{\prime} \mathrm{S} 58^{\circ} 00^{\prime} \mathrm{W}$ ).

A negligible sum of 0.28 TDD was observed for air temperature, with $-14,430.7$ FDD (Fig. 5). Soil moisture regime for both profiles is aridic, with readings always below $10 \%$ in soil water content. The exposed soil P1 has $2 \%$ of moisture during most of the studied period, reaching a

Table 3

Monthly averages for Air and soil temperature $\left({ }^{\circ} \mathrm{C}\right)$, ATD and N Factor at P1 and P2.

\begin{tabular}{|c|c|c|c|c|c|c|c|c|c|c|c|}
\hline Temp $\left({ }^{\circ} \mathrm{C}\right)$ & $\mathrm{P} 15 \mathrm{~cm}$ & $\mathrm{P} 110 \mathrm{~cm}$ & $\mathrm{P} 130 \mathrm{~cm}$ & $\mathrm{P} 25 \mathrm{~cm}$ & P2 $10 \mathrm{~cm}$ & P2 $30 \mathrm{~cm}$ & AIR & ATD P1 & ATD P2 & N_Fac. P1 & N_Fac. P2 \\
\hline 12-Jan & -3.3 & -4.5 & -5.4 & -4.5 & -5.6 & -5.9 & -10.0 & $-1.2 \mathrm{E}-03$ & $-8.1 \mathrm{E}-06$ & 0.4 & 0.5 \\
\hline 12-Feb & -8.8 & -8.9 & -9.0 & -8.8 & -9.2 & -9.2 & -11.6 & $2.2 \mathrm{E}-05$ & $4.9 \mathrm{E}-05$ & 0.8 & 0.8 \\
\hline 12-Mar & -16.9 & -15.8 & -15.0 & -16.4 & -16.0 & -15.2 & -18.0 & $2.8 \mathrm{E}-06$ & $6.6 \mathrm{E}-07$ & 0.9 & 0.9 \\
\hline 12-Apr & -26.6 & -24.5 & -22.9 & -25.6 & -24.3 & -22.8 & -25.7 & $-1.2 \mathrm{E}-07$ & $-6.4 \mathrm{E}-07$ & 1.0 & 1.0 \\
\hline 12-May & -25.2 & -24.1 & -23.4 & -24.6 & -23.9 & -23.2 & -24.1 & $1.3 \mathrm{E}-06$ & $5.7 \mathrm{E}-07$ & 1.0 & 1.0 \\
\hline 12-Jun & -27.5 & -26.4 & -25.6 & -26.9 & -26.2 & -25.5 & -26.2 & $1.7 \mathrm{E}-06$ & $1.3 \mathrm{E}-06$ & 1.0 & 1.0 \\
\hline 12-Jul & -29.0 & -27.7 & -26.7 & -28.4 & -27.5 & -26.6 & -28.6 & $-8.2 \mathrm{E}-07$ & $-1.1 \mathrm{E}-06$ & 1.0 & 1.0 \\
\hline 12-Aug & -29.4 & -28.5 & -27.9 & -29.1 & -28.3 & -27.6 & -28.9 & $7.7 \mathrm{E}-07$ & $6.9 \mathrm{E}-07$ & 1.0 & 1.0 \\
\hline 12-Sep & -28.6 & -28.0 & -27.5 & -28.1 & -27.6 & -27.2 & -27.5 & $2.0 \mathrm{E}-06$ & $1.9 \mathrm{E}-06$ & 1.0 & 1.0 \\
\hline $12-$ - ct & -18.7 & -20.2 & -21.2 & -19.3 & -20.1 & -20.9 & -20.1 & $2.3 \mathrm{E}-05$ & $1.5 \mathrm{E}-05$ & 0.9 & 1.0 \\
\hline 12-Nov & -8.7 & -11.4 & -13.3 & -10.6 & -12.2 & -13.6 & -14.0 & $5.4 \mathrm{E}-06$ & $1.6 \mathrm{E}-04$ & 0.6 & 0.8 \\
\hline 12-Dec & 2.0 & -1.9 & -4.8 & -1.2 & -3.3 & -5.2 & -5.9 & $3.2 \mathrm{E}-04$ & $2.1 \mathrm{E}-04$ & 0.1 & 0.3 \\
\hline Avg 2012 & -18.4 & -18.5 & -18.6 & -18.6 & -18.7 & -18.6 & -20.1 & $-6.8 \mathrm{E}-05$ & $3.6 \mathrm{E}-05$ & 0.8 & 0.8 \\
\hline 13-Jan & 0.5 & -1.3 & -2.6 & -1.3 & -2.8 & -3.1 & -6.7 & $-8.2 \mathrm{E}-04$ & $-4.7 \mathrm{E}-04$ & 0.2 & 0.3 \\
\hline 13-Feb & -9.4 & -9.2 & -9.0 & -9.6 & -9.8 & -9.5 & -14.4 & $4.9 \mathrm{E}-06$ & $-4.8 \mathrm{E}-06$ & 0.7 & 0.7 \\
\hline 13-Mar & -15.5 & -14.7 & -14.0 & -15.3 & -14.5 & -14.1 & -16.8 & $1.5 \mathrm{E}-05$ & $2.0 \mathrm{E}-05$ & 0.9 & 0.9 \\
\hline 13-Apr & -23.7 & -21.7 & -20.2 & -23.3 & -21.1 & -20.1 & -23.4 & $-1.9 \mathrm{E}-06$ & $-2.1 \mathrm{E}-06$ & 1.0 & 1.0 \\
\hline 13-May & -26.5 & -25.0 & -23.8 & -26.1 & -24.5 & -23.7 & -25.1 & $5.3 \mathrm{E}-07$ & $3.3 \mathrm{E}-07$ & 1.1 & 1.0 \\
\hline 13-Jun & -25.4 & -24.7 & -24.2 & -25.1 & -24.4 & -24.1 & -23.6 & $2.7 \mathrm{E}-06$ & $2.3 \mathrm{E}-06$ & 1.1 & 1.1 \\
\hline 13-Jul & -31.3 & -29.2 & -27.6 & -30.8 & -28.6 & -27.5 & -29.6 & $1.7 \mathrm{E}-07$ & $6.2 \mathrm{E}-08$ & 1.1 & 1.0 \\
\hline 13-Aug & -27.0 & -26.5 & -26.1 & -26.7 & -26.2 & -26.0 & -25.5 & $9.4 \mathrm{E}-07$ & $7.1 \mathrm{E}-07$ & 1.1 & 1.0 \\
\hline 13-Sep & -25.7 & -25.7 & -25.6 & -25.3 & -25.4 & -25.4 & -24.2 & $3.7 \mathrm{E}-06$ & $3.9 \mathrm{E}-06$ & 1.1 & 1.0 \\
\hline 13-Oct & -20.9 & -21.5 & -21.8 & -20.6 & -21.3 & -21.5 & -22.0 & $9.9 \mathrm{E}-06$ & $1.1 \mathrm{E}-05$ & 0.9 & 0.9 \\
\hline 13-Nov & -11.1 & -13.3 & -15.1 & -11.8 & -14.2 & -15.3 & -14.7 & $1.1 \mathrm{E}-04$ & $2.0 \mathrm{E}-03$ & 0.8 & 0.8 \\
\hline 13-Dec & -0.9 & -4.0 & -6.7 & -2.6 & -5.6 & -6.9 & -7.6 & $-2.1 \mathrm{E}-03$ & $-1.3 \mathrm{E}-03$ & 0.2 & 0.4 \\
\hline Avg 2013 & -18.1 & -18.1 & -18.1 & -18.2 & -18.2 & -18.1 & -19.5 & $-2.3 \mathrm{E}-04$ & $2.2 \mathrm{E}-05$ & 0.8 & 0.8 \\
\hline Global Avg & -18.2 & -18.3 & -18.3 & -18.4 & -18.4 & -18.3 & -19.8 & $-1.5 \mathrm{E}-04$ & $2.9 \mathrm{E}-05$ & 0.8 & 0.8 \\
\hline
\end{tabular}



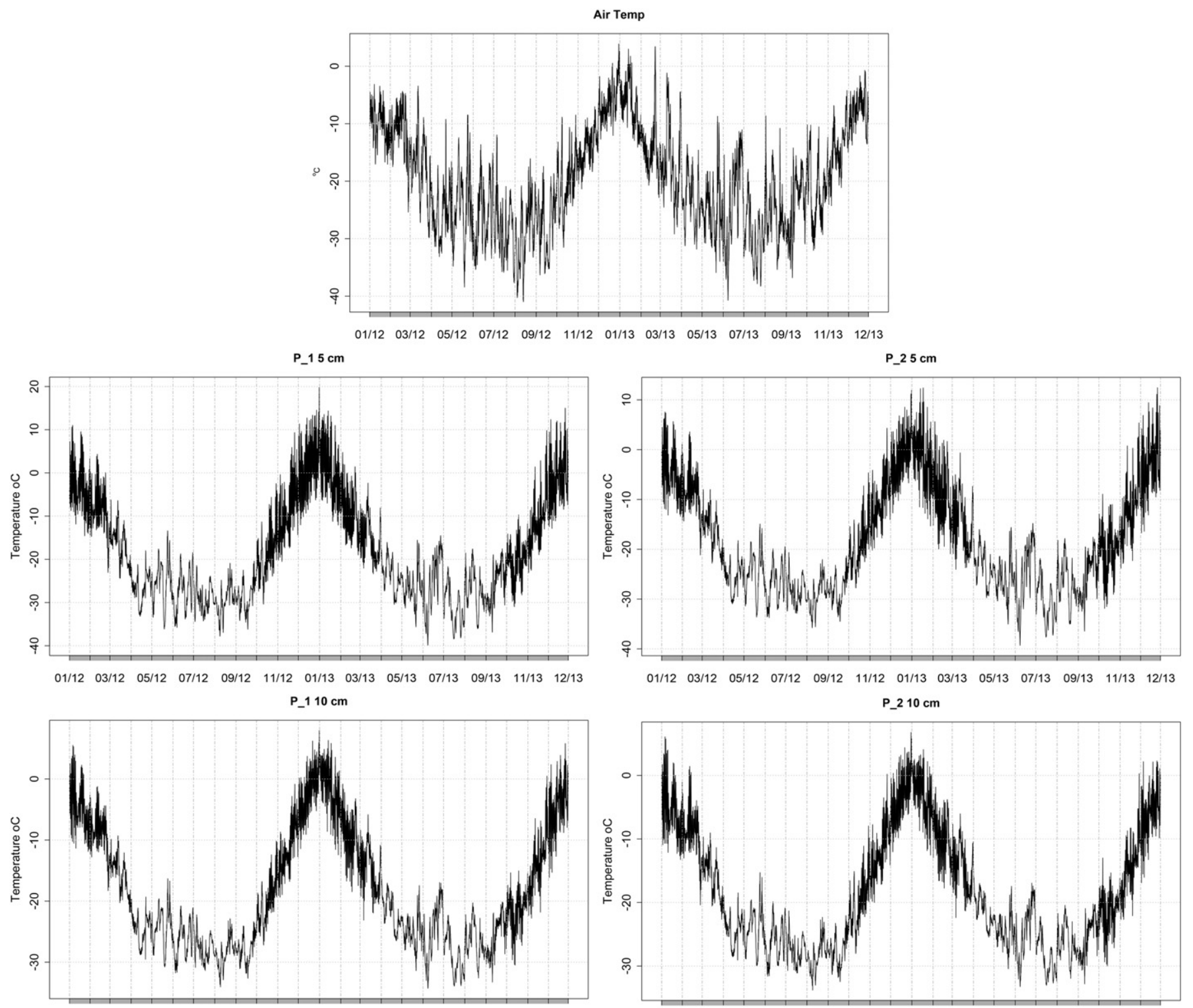

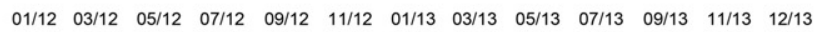

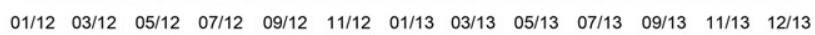

P_1 $30 \mathrm{~cm}$
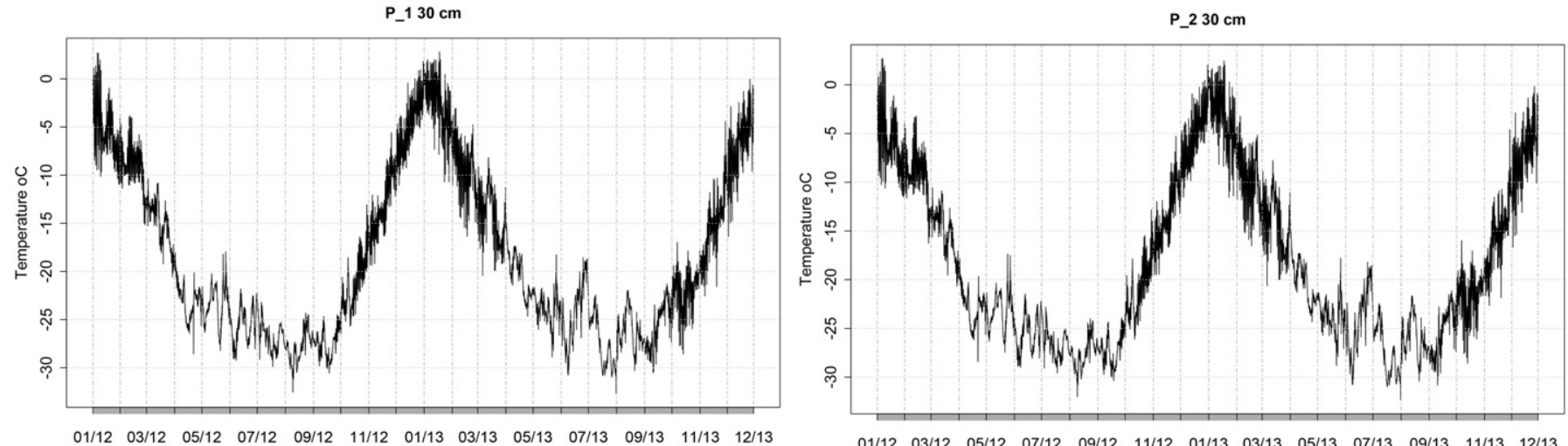

Fig. 3. Hourly air and soil temperature data at P1 and P2.

maximum of 3\%. The sheltered soil P2 showed a more variable dynamics, with readings below 2\% in most of 2012 and between 2 and 3\% during 2013, with some minor fluctuations during the summer season (close to $10 \%$ ), indicating water redistribution at very short spells (Fig. 6).
The apparent thermal diffusivity for the studied period followed similar tendencies for both soils, although mean values for the whole period were $-1.5 \mathrm{E}^{-4} \mathrm{~m}^{2} \mathrm{~s}^{-1}, 3.0 \mathrm{E}^{-5} \mathrm{~m}^{2} \mathrm{~s}^{-1}$. Lower values are reported at Scott base $\left(1.2 \times \mathrm{E}^{-7} \mathrm{~m}^{2} \mathrm{~s}^{-1}\right)$, Table Mountain $\left(1-30 \mathrm{E}^{-4} \mathrm{~m}^{2} \mathrm{~s}^{-1}\right.$ and in the McMurdo Dry Valleys $\left(1.4 \times \mathrm{E}^{-7} \mathrm{~m}^{2} \mathrm{~s}^{-1}, 3.7 \mathrm{E}-8 \mathrm{~m}^{2} \mathrm{~s}^{-1}\right)$ 


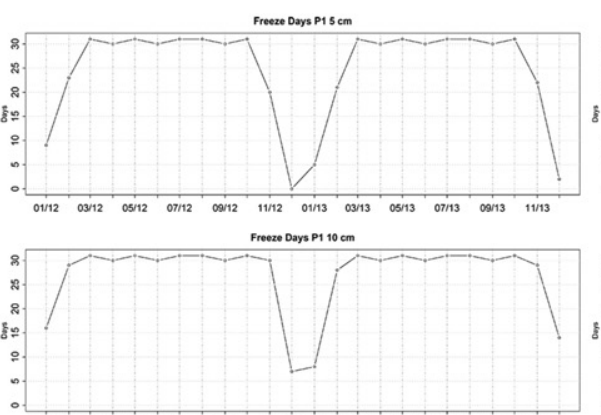

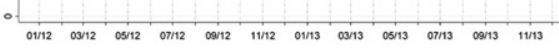

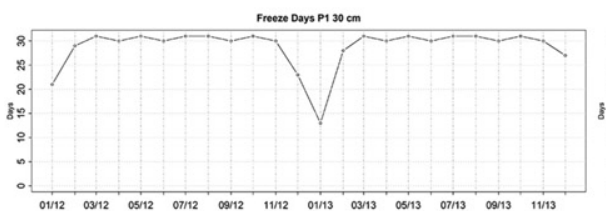

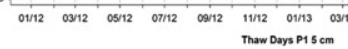

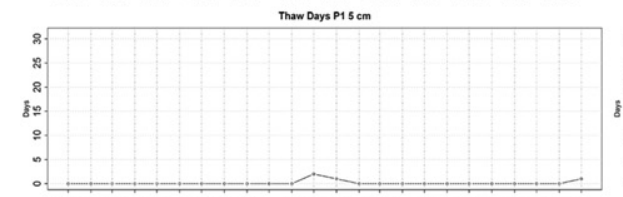

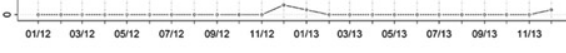
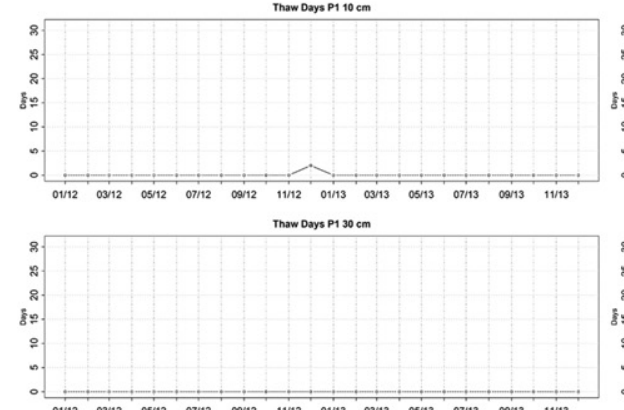

1012
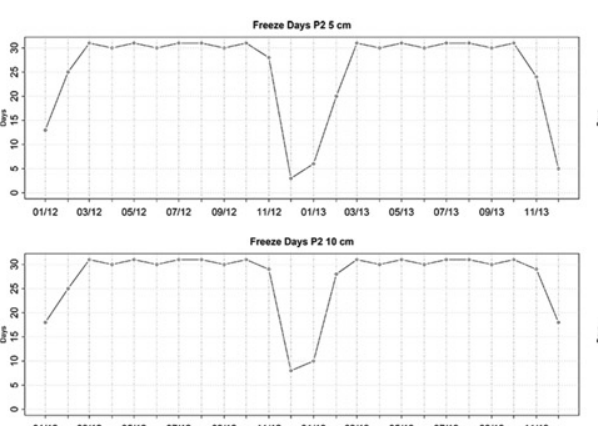

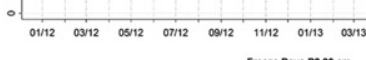

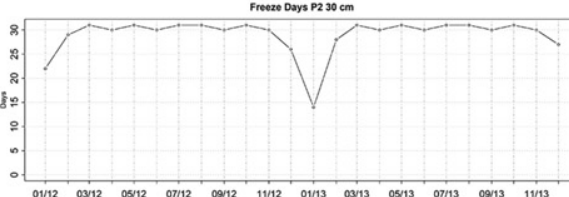

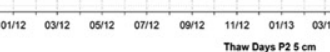

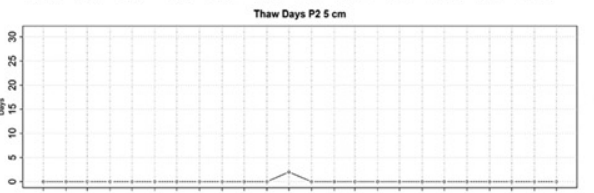

Tham Dors pe $10 \mathrm{~cm}$
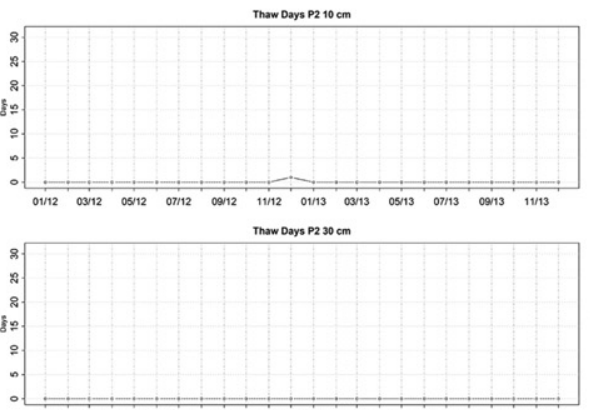

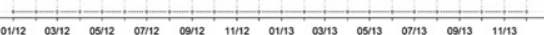

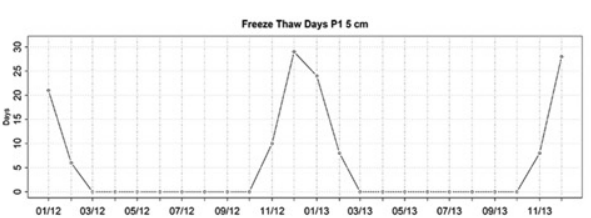

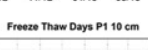

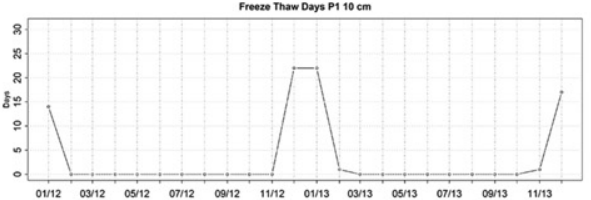

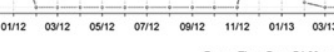
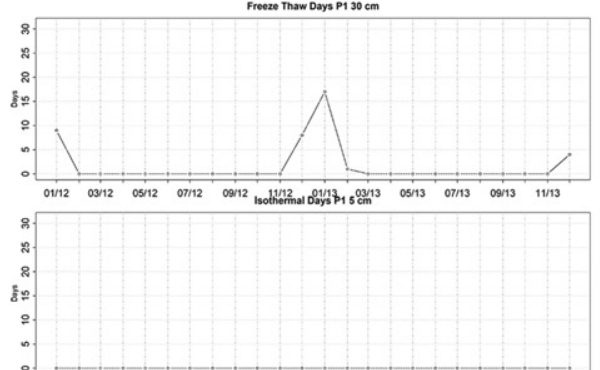

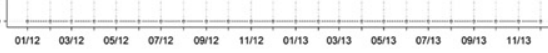

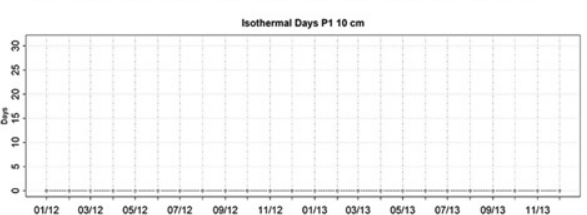

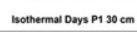

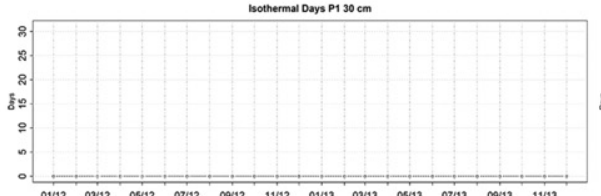

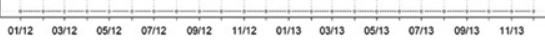

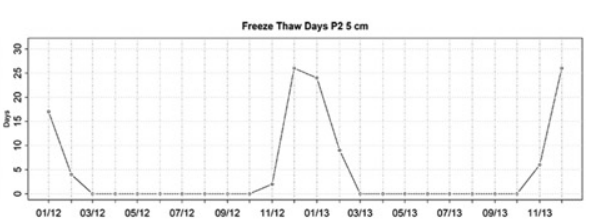

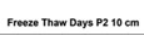

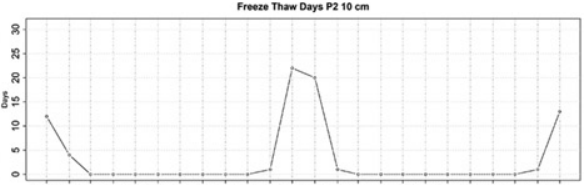

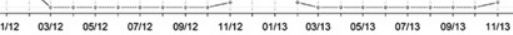

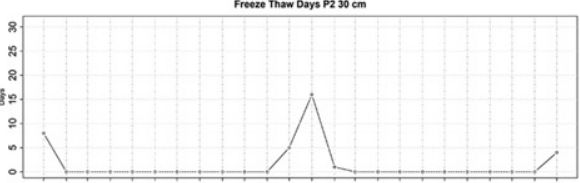

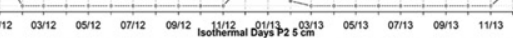

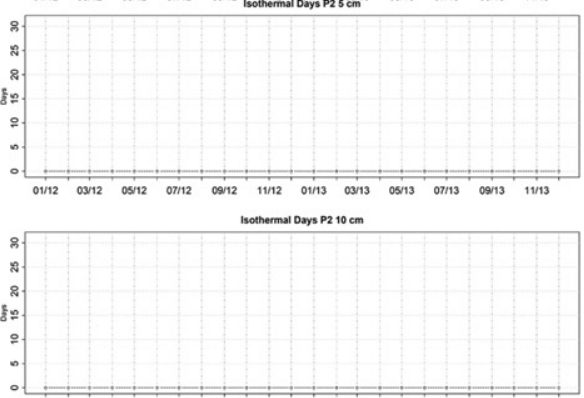

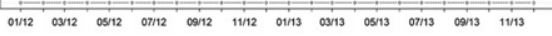

Hothemst Doss p p $30 \mathrm{~cm}$

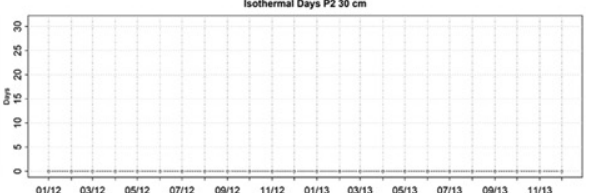

Fig. 4. Thawed days, frozen days, isothermal days and freeze thaw days recorded for P1 and P2. 

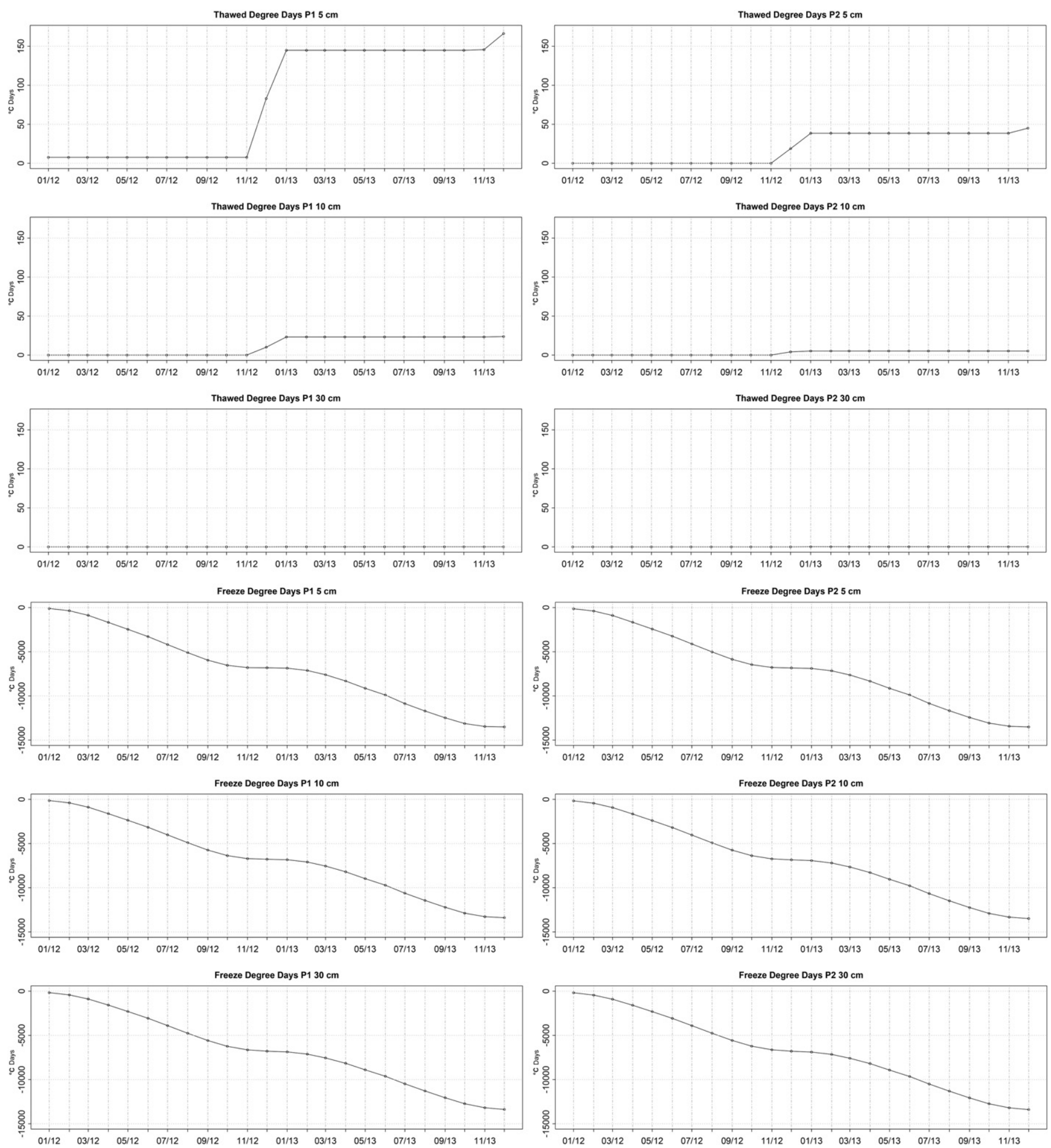

Fig. 5. Thawed degree days and freeze degree days at P1 and P2.

(Pringle et al., 2003; Adlam et al., 2010; Ikard et al., 2009). Monthly values were frequently positive for warmer seasons and negative at the peak of winter and summer at both sites, negative values were higher at the highest, more exposed site (P1). When calculated for each season, the spring presents the greatest values (around $-1.5 \mathrm{E}^{+1} \mathrm{~m}^{2} \mathrm{~s}^{-1}$ ), while the summer has the smallest values (around $\left.-8.2 \mathrm{E}^{+0} \mathrm{~m}^{2} \mathrm{~s}^{-1}\right)$.

Histograms show a greater frequency of temperatures around $-30^{\circ} \mathrm{C}$ in at the $5 \mathrm{~cm}$ soil layer for both profiles whereas at 10 and $30 \mathrm{~cm}$ temperature readings were mostly around -20 and $-30{ }^{\circ} \mathrm{C}$. The freezing $\mathrm{n}$-factor varied greatly, values close to 1 are concentrated in the winter months and values around 0.25 are recorded at the warmer months (Table 3).

The additional decomposition of the hourly time series showed a similar behavior for both soils, depicting a strong seasonal component with greater amplitude during the summer. The sheltered site P2 showed daily amplitudes close to $12{ }^{\circ} \mathrm{C}$ (Fig. 7). The remaining component of the time series fluctuates between -4 and $4{ }^{\circ} \mathrm{C}$, more intensely 

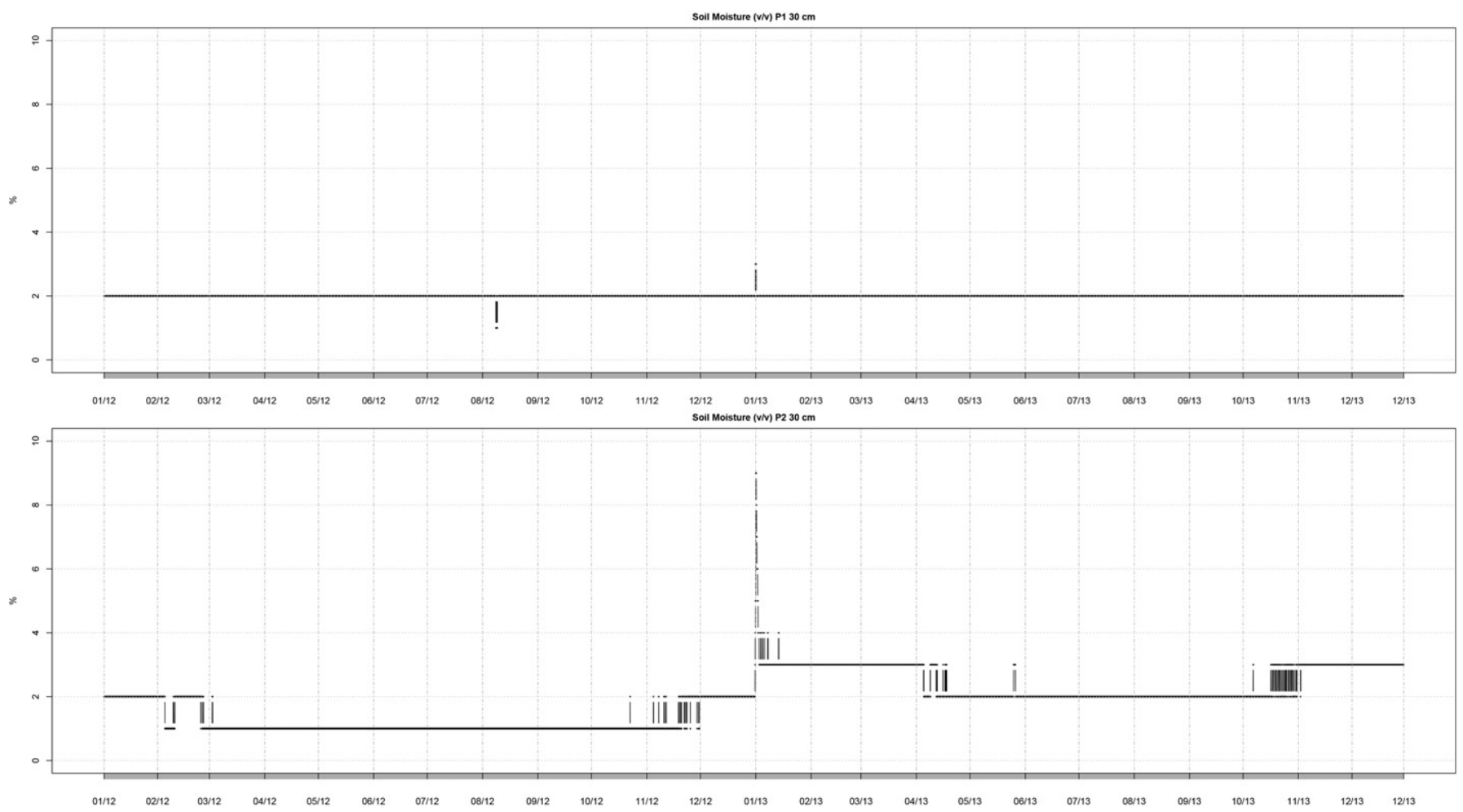

Fig. 6. Soil moisture $(v / v)$, at $\mathrm{p} 1$ and $\mathrm{p} 2$.

during the summer months. First difference plots illustrates how intense temperature changes are at one-hour intervals, calculated values were around $6{ }^{\circ} \mathrm{C}$, values reached $4{ }^{\circ} \mathrm{C}$ in winter even at deeper layers, variations are concentrated in the warmer months (Fig. 8).

Multivariate regressions (dependent on air, $5 \mathrm{~cm}$ and $10 \mathrm{~cm}$ layers) were employed to estimate the temperature at $30 \mathrm{~cm}$, the adjusted Rsquared was 0.98 at both sites, and standard errors for the coefficients were small (Table 4$)$. The closest overlying layer $(10 \mathrm{~cm})$ influenced the results greatly, whereas higher coefficients were found for air and $5 \mathrm{~cm}$ layer for the sheltered soil (P2); overall the contribution of air and topsoil temperatures $(5 \mathrm{~cm}$ ) was small (Fig. 9). All coefficients were statistically significant. The equations proposed at both sites effectively predicted temperatures at the bottom layer, overestimating temperature peaks. Maximum and minimum residuals were 3.71, 4.39 and $-4.60,-4.55$ for $\mathrm{P} 1$ and $\mathrm{P} 2$ respectively.

The first diagnostic plot (Fig. 10) seems to indicate that the residuals and the fitted values are not correlated at both sites. The qq-plot shows the points curving away from the line at each end, in opposite directions; the data is heavy tailed and right skewed, which indicates the distribution of the standardized residuals is more concentrated at the tails, particularly at the right one. The scale-location plot, in which the raw residuals are standardized by their estimated standard deviations, is used to detect if the spread of the residuals is constant over the range of fitted values. We observed a slight trend of more variance with high values. The standardized residuals leveraged against each data point, shows which points are exerting most influence. A group of points with positive standardized residuals exerted great leverage (P2), but still cannot be considered outliers.

\section{Discussion}

Although located close by, both sites represent different geomorphological positions in landscape (convex; exposed P1 and concave; sheltered P2), with rather similar thermal regimes. P1 is located at a middle slope convex elevated site on a moraine of Mt. Dolence (8-20\% slope); P2 is located on the lower part of the same moraine, close to a small snowfield with a steep slope (20-45\%). P2 is colder than P1 in summer and warmer in winter throughout the profile, corroborating a buffering exposition to wind at the lower areas during the winter months, and shade in the warmer months. These factors result in a slightly deeper active layer found at the convex-exposed site (P1). Adlam et al. (2010) found active layer depth to be significantly influenced by mean summer air temperature, mean winter air temperature, total summer solar radiation and mean summer wind speed, when analyzing seven sites in the McMurdo Sound Region.

ATD can be interpreted for all seasons since there is little influence of soil moisture and water percolation along the profile. ATD values are higher during frozen conditions when soil moisture is available, given that the thermal conductivity of ice is much greater than that of liquid water; a decrease in ATD and in its variability was observed with decreasing soil moisture at the McMurdo Dry Valleys (Ikard et al., 2009). Results suggest that P2 is less resistant in transmitting energy, though the actual thermal conductivity of both profiles is very similar. High negative values for P1 in summer and winter are caused by its exposed position; which allows great warming near the surface in the summer, and cooling in winter. At milder seasons, the energy flow is similar to summer and winters, but larger values of ATD are calculated due to smaller differences in temperature in the profile. The classification of the daily temperature cycle also suggests that P2 is colder, since it recorded more FD on the studied period for all layers. The cumulative sum of temperatures reveals remarkably similar results; differences in landscape position are annulled, since P1 is warmer in summer and colder in winter.

The slope movements that happen in the Mt. Dolence area, which are responsible for the detritus flow, are different from the hillslopes processes that occur in more humid regions of the Antarctica. In studies developed in areas under humid and warm climatic conditions from the Maritime Antarctica, the movement processes of detritus in slopes 

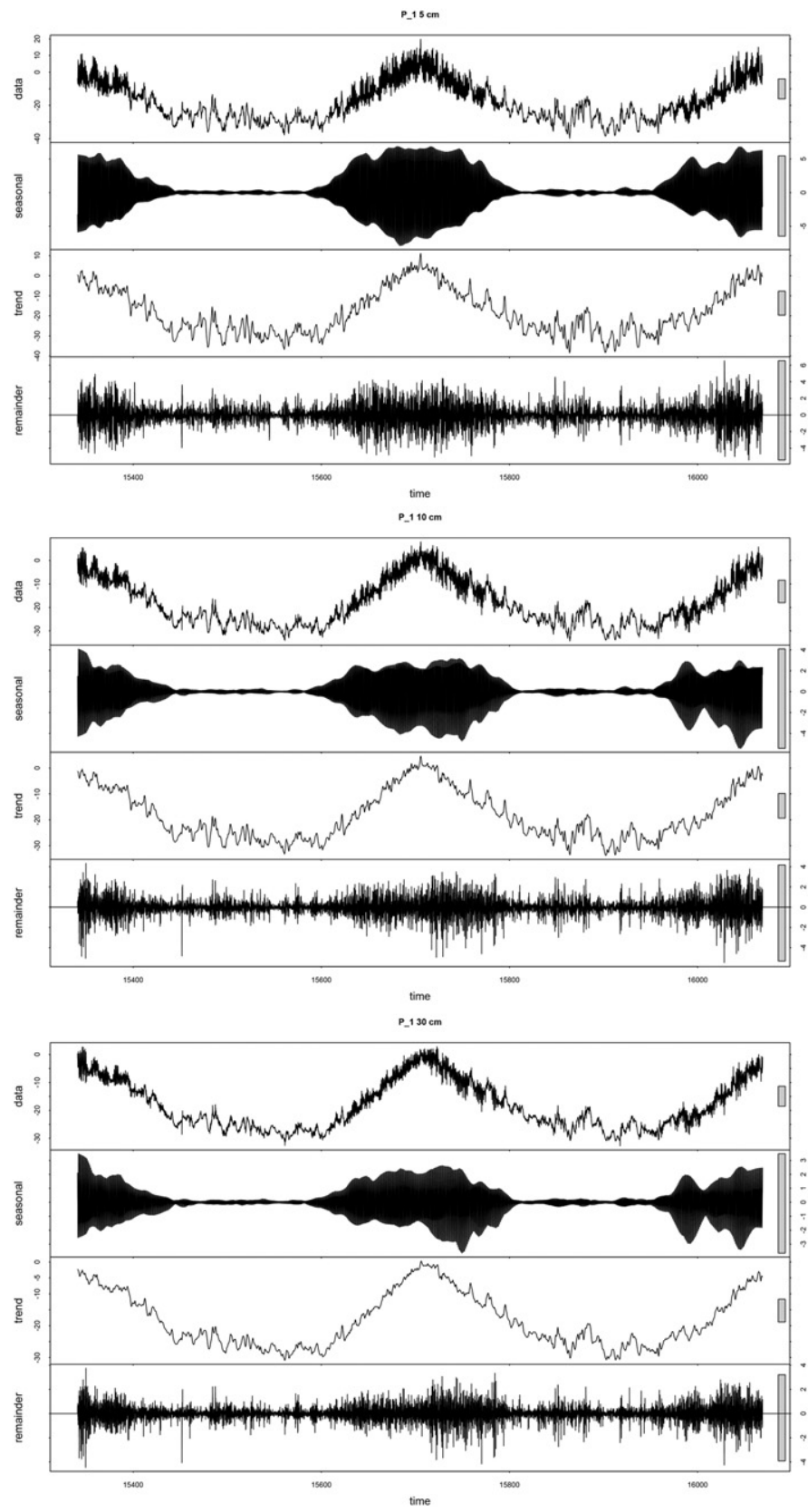
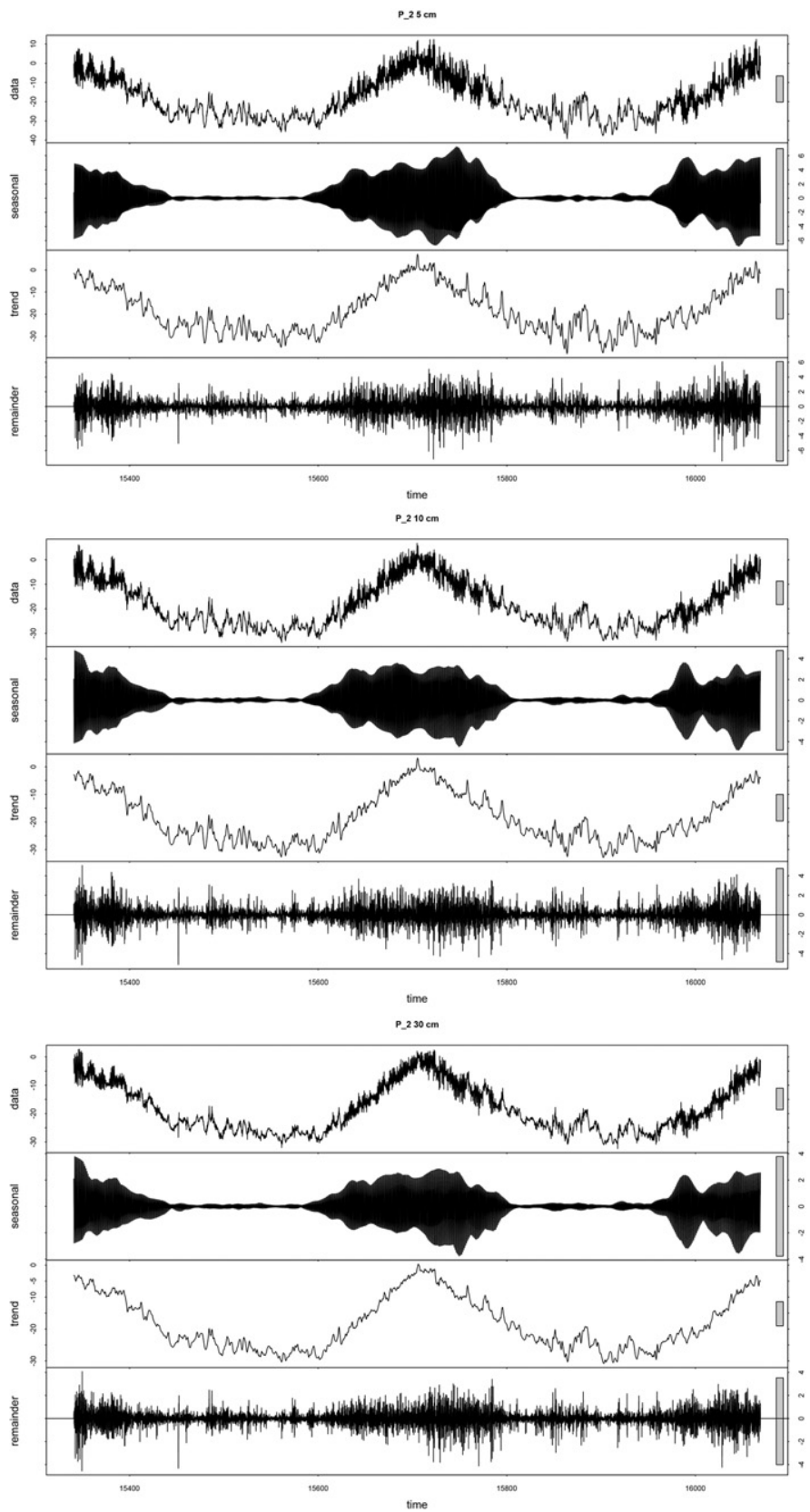

Fig. 7. Additional decomposition of the hourly time series at P1 and P2.

happen mainly from the gelifluction, a process highly related to the active layer dynamics (Francelino et al., 2011; Rosa et al., 2013; Michel et al., 2014). On the other hand, in Ellsworth, due to the extremely low temperatures experimented throughout the year and limited moisture offer, the detritus flow take place from the movements caused by the variation of horizontal and vertical temperatures produced by radiation and winds. This behavior was reported by Vieira and Simões (2011) in the Independence and Patriot Hills, also located in the south of the Ellsworth Mountains.

The periglacial features like the morainic system and the patterned ground, found in the lower parts of the slope, have moisture carried by the ablation of the blue ice glacier. However, such ablation zones are practically inactive; taking into consideration the extremely low temperatures experimented by the Ellsworth Mountains throughout the year. It is possible that these features are products from more humid times, when temperatures surpassed $0{ }^{\circ} \mathrm{C}$ and the periglacial processes were more active. Carrasco et al. (2000) registered events of positive temperatures in a recent past, which represent moments of eventual deglaciation, responsible for the supply of moisture to the environment. This moisture is eventually able to counterbalance sublimation sustaining periglacial features in the cold desert landscape of the Ellsworth Mountains.

Soil water content varied according to the different positions of the profiles. P1 presented lower values (around 2\%) and very small fluctuations due to its more exposed position, less subjected to snow accumulation and influenced by a smaller drainage area. P2 recorded values below $2 \%$ for 2012 and close to 3\% for 2013, with more intense variations, peaking unusual $10 \%$ in soil water content in January 2013. Overall the water content is around $2 \%$ and had little influence on the temperature regime of both profiles.

The absence of the zero curtain effect changes the distribution of the temperature readings, concentrating most of the readings at the -30 to 

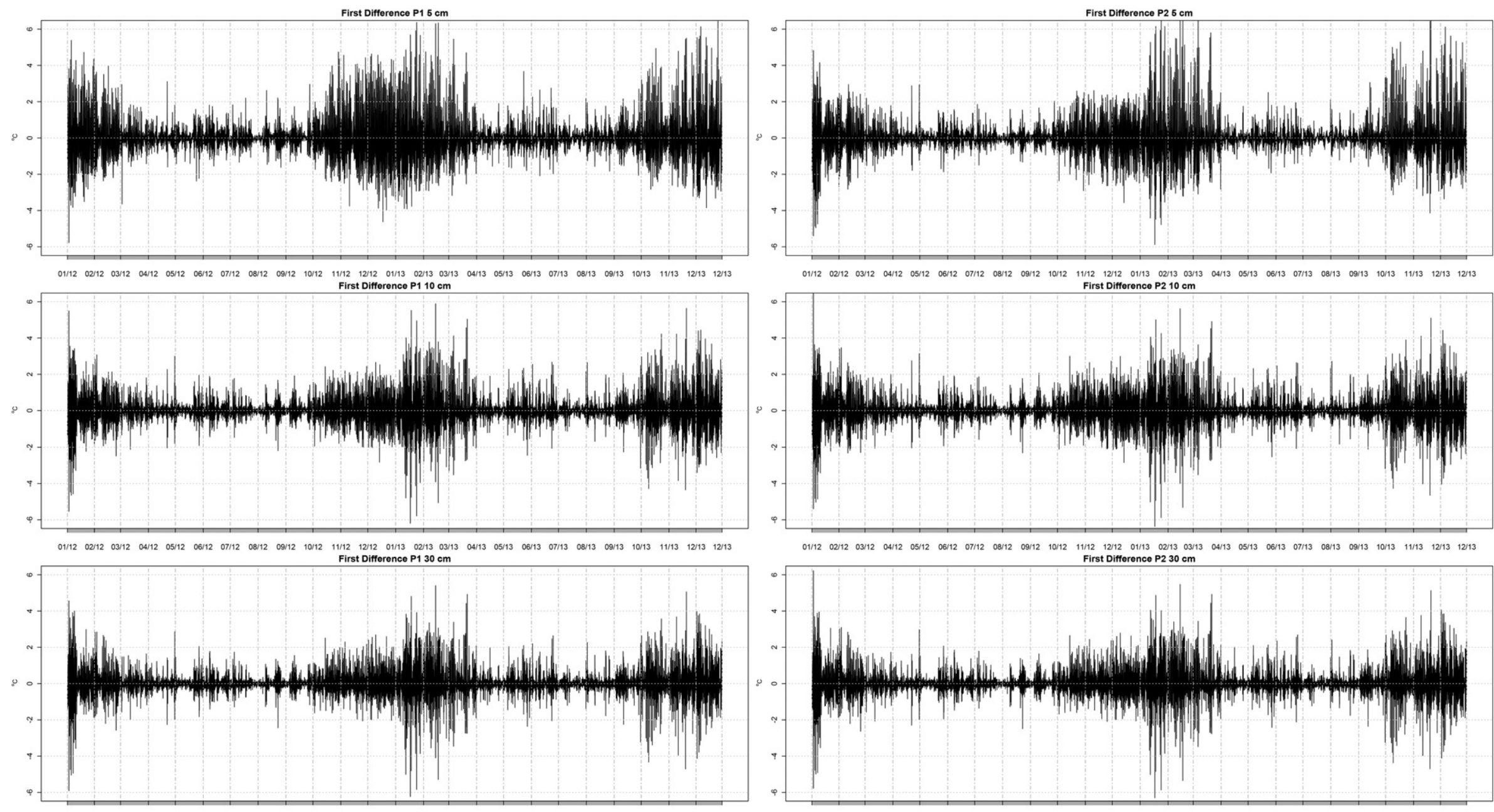

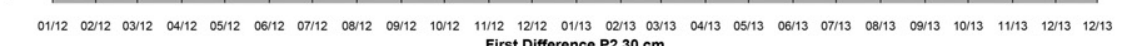

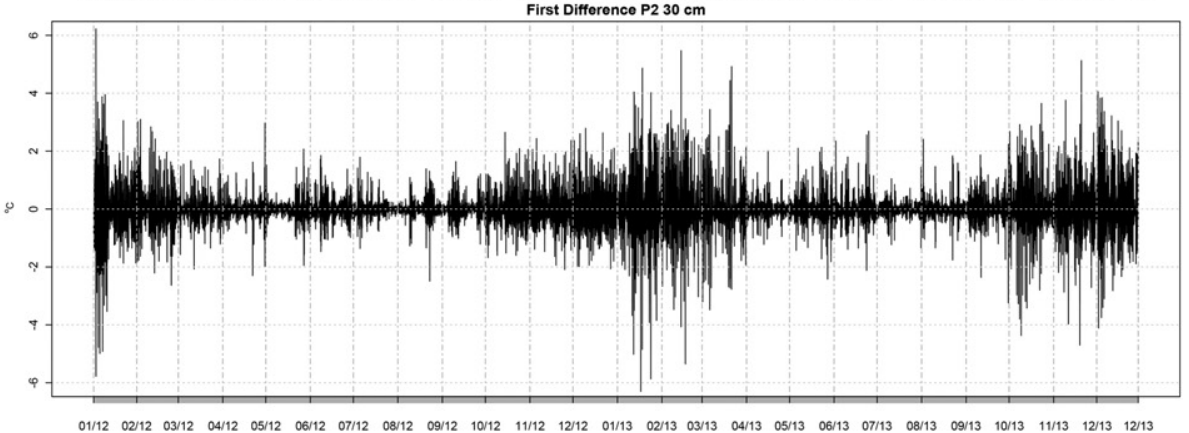


Table 4

Parameters and equation of multivariate regressions of temperature at $30 \mathrm{~cm}$ at P1 and P2 (dependent on air, $5 \mathrm{~cm}$ and $10 \mathrm{~cm}$ layers).

\begin{tabular}{|c|c|c|c|}
\hline Site & Equation & Adjusted $\mathrm{R}^{2}$ & Standard error intercept and coefficients \\
\hline P_1 & Tsoil $30 \mathrm{~cm}=-1.412984-0.006439 \times$ Tair $-0.006439 \times$ Tsoil $5 \mathrm{~cm}+1.284377 \times$ Tsoil $10 \mathrm{~cm}$ & 0.9865 & $\begin{array}{l}\text { Intercept (0.0232) Tair (0.0022); Tsoil } 5 \mathrm{~cm}(0.0029) \text {; } \\
\text { Tsoil } 10 \mathrm{~cm}(0.0030)\end{array}$ \\
\hline P_2 & Tsoil $30 \mathrm{~cm}=-1.131452-0.063202 \times$ Tair $-0.287949 \times$ Tsoil $5 \mathrm{~cm}+1.287976 \times$ Tsoil $10 \mathrm{~cm}$ & 0.9886 & $\begin{array}{l}\text { Intercept (0.0205) Tair (0.0020); Tsoil } 5 \mathrm{~cm} \text { (0.0034); } \\
\text { Tsoil } 10 \mathrm{~cm}(0.0035)\end{array}$ \\
\hline
\end{tabular}

$-20^{\circ} \mathrm{C}$. The energy flow in the profile depends only on the conductivity of its constituents and the insulating effect of air in its pores; soil moisture plays a very small part intermediating heat flow. Temperature changes are commonly abrupt, as evidenced by the first difference plots, Vieira et al. (2012) recorded similar behavior on soils developed from drift deposits at Independence and Patriot Hills.

The absence of snow is noticeable, and the evolution of the freezing $\mathrm{n}$-factor during the year is extreme; values are very close to 1 during winter, decreasing to nearly zero during the summer. The small values found in the summer are not caused by any insulation effect of snow cover, but are due to direct solar energy input, preventing strong temperature fall in surface. Summer is also when both sites show different values, always smaller at P2. Winter values close to 1 suggest great influence of air temperatures on ground temperatures, corroborating with ATD results.

The additive decomposition of the time series allows an analysis of the different components of the data. The seasonal component yields the variation in the data near the seasonal frequency, in our case one cycle per day. The trend component illustrates the low frequency variation in the data together with no stationary, long-term changes. The decomposition of the time series reveals great seasonal component associated with the summer, especially for 2014, with larger amplitude at P1, decreasing with depth. The daily trend fits well as a smoothed time series, similarly for all depths at both sites. Most of the noise is concentrated in the warmer months although the low moisture content allows great variation throughout the year; noise amplitude is similar for all horizons.

The equations proposed through stepwise regression presented satisfactory adjust to the recorded data, helping us to understand the linear effect of each independent variable in predicting temperature of the bottom layer (dependent variable). It also reflects how the energy flows from the atmosphere to the soil. Little overestimation is observed near peak values, with a uniform behavior throughout the studied period. Slight difference is observed between sites, the sheltered site P2 presented a better fit with greater influence of the $5 \mathrm{~cm}$ layer due to smaller temperature fluctuations near the surface.

\section{Conclusions}

1) The soil thermal regime at the dry valley of Mt. Dolence, Ellsworth Mountains is characteristic of cold desert affected by dry-frozen permafrost. Although air temperature does not reach high positive values, variations in soil temperature are more intense during the summer, showing the soil's response to solar radiation.

2) The periglacial landforms such as garlands, stone stripes and other pattern-ground features observed at the surface at both sites, are not in phase with the present cold desert climate, and may be related to past warmer events or wetter periods; although during the
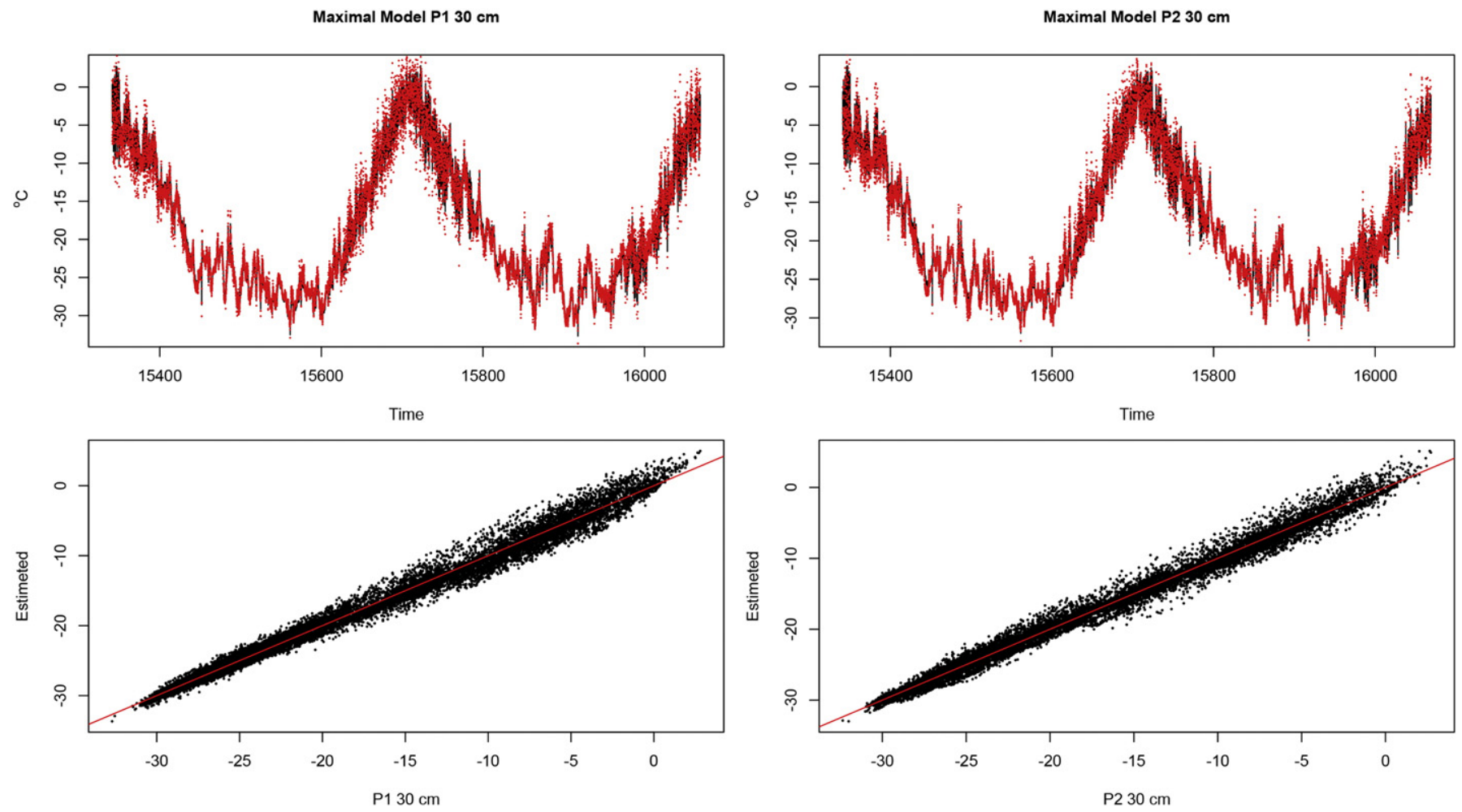

Fig. 9. Multivariate regressions of temperature at $30 \mathrm{~cm}$ at $\mathrm{P} 1$ and $\mathrm{P} 2$ (dependent on air, $5 \mathrm{~cm}$ and $10 \mathrm{~cm}$ layers). 

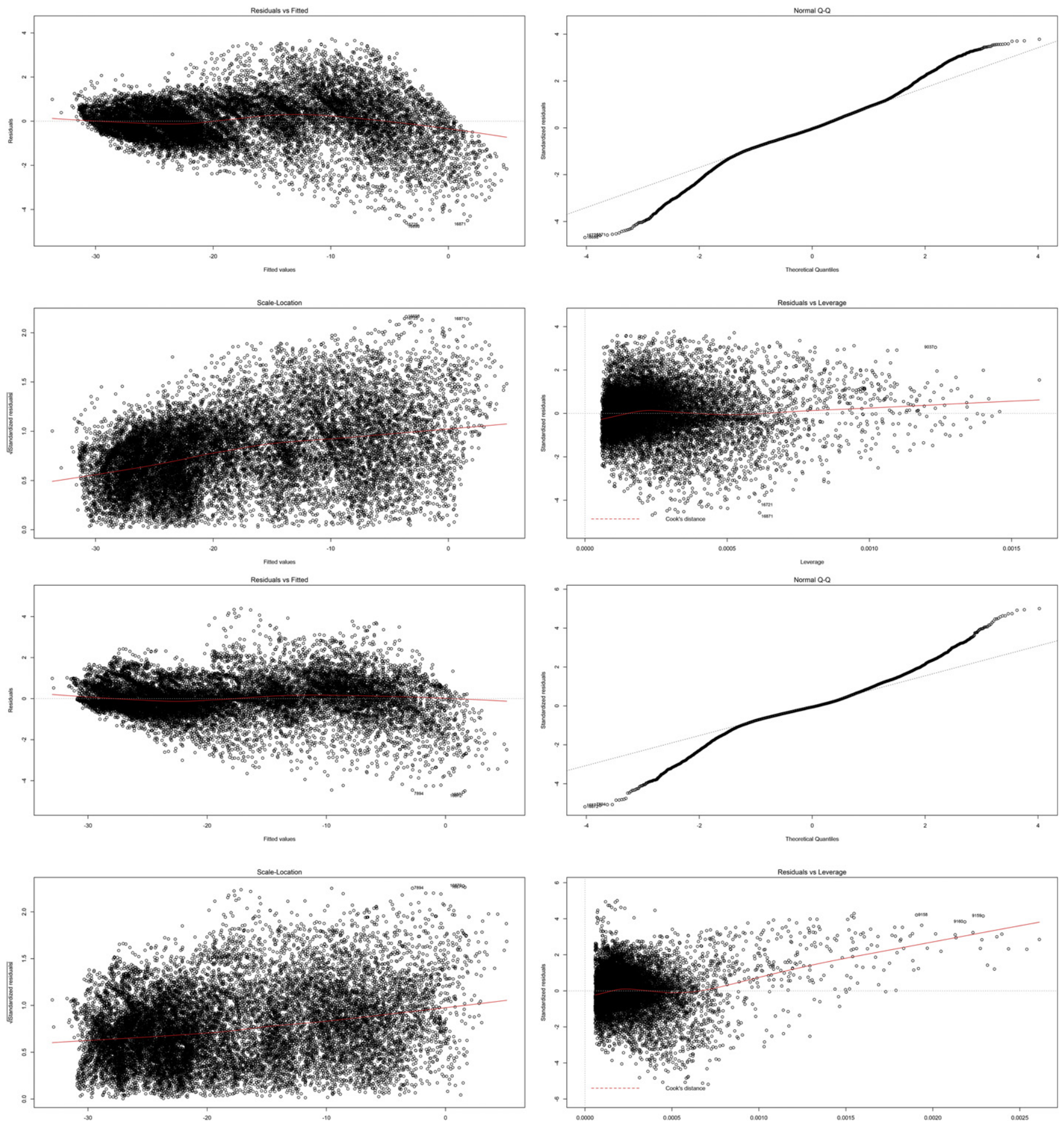

Fig. 10. Diagnostic plots of multivariate regressions of temperature at $30 \mathrm{~cm}$ at $\mathrm{P} 1$ and $\mathrm{P} 2$.

summer peak there are enough events of positive temperatures and melting that explain the periglacial features observed. Hence, the landscape dynamics evolves under scarce conditions that last for very short times, but operate to create conditions for long lasting landforms.

3) The exposed convex site is more prone to temperature extremes than the concave sheltered site with a salt-pan surface. It is warmer in summer and colder in winter, resulting in greater active layer thickness.

4) The active-layer is subjected to strong sublimation of water, so that subsurface moisture content and redistribution are negligible.
5) The thermal regime of dry permafrost at the Ellsworth is comparable to other continental areas such as the dry-valleys of Victoria Land.

\section{Acknowledgments}

This study was funded by CAPES and CNPq (MCTI/CNPq/FNDCT Ação Transversal no. 64/2013). This research is a contribution of the TERRANTAR Laboratory of the Brazilian National Science and Technology Institute for the Cryosphere (INCT Criosfera). 


\section{References}

Adlam, L.S., Balks, M.R., Seybold, C.A., Campbell, D.I., 2010. Temporal and spatial variation in active layer depth in the McMurdo Sound Region, Antarctica. Antarct. Sci. 221, 45-52.

Black, R.F., Berg, T.E., 1963. Hydrothermal regimen of patterned ground, Victoria Land, Antarctica. Int. Assoc. Sci. Hydrol. Comm. Snow Ice 61, 121-127.

Bockheim, J.G., 1993. Global Change and Soil Formation in Antarctica in Joint RussianAmerican Seminar on Cryopedology and Global Change. Russian Academy of Sciences, Pushchino, pp. 132-140.

Bockheim, J.G., 1995. Permafrost distribution in the southern circumpolar region and its relation to the environment: a review and recommendations for further research. Permafr. Periglac. Process. 6, 27-45.

Bockheim, J.G., 2002. Landform and soil development in the McMurdo Dry Valleys, Antarctica: a regional synthesis. Arct. Antarct. Alp. Res. 34 (3), 308-317.

Bockheim, J.G., McLeod, M., 2008. Soil distribution in the McMurdo Dry Valleys, Antarctica. Geoderma 144, 43-49.

Bockheim, J.G., Schaefer, C.E.G.R., 2015. Soils of Ellsworth Land, the Ellsworth Mountains. In: Bockheim, J.G. (Ed.), The Soils of Antarctica. World Soils Book Series. Springer, Switzerland, pp. 169-181.

Bockheim, J.G., Tarnocai, C., 1998. Nature, occurrence and origin of dry permafrost. In: Lewkowicz, A.G., Allard, M. (Eds.), Proc. Seventh International Conference on Permafrost. Collection Nordica (Université Laval) 57, pp. 57-64.

Cameron, R.E., 1969. Cold desert characteristics and problems relevant to other arid lands. In: McGinnies, W.G., Goldman, B.J. (Eds.), Arid Lands in Perspective. University of Arizona Press, Tucson, pp. 167-205.

Campbell, I.B., Claridge, G.G.C., Balks, M.R., 1994. The effect of human activities on moisture content of soils and underlying permafrost from the McMurdo Sound region, Antarctica. Antarct. Sci. 6, 307-314.

Carrasco, J.F., Casassa, G., Rivera, A., 2000. A warm event at Patriot Hills, Antarctica: an ENSO related phenomenon? Sixth International Conference on Southern Hemisphere Meteorology and Oceanography, 2000. Santiago. American Meteorological Society, Boston, pp. 240-241

Cartwright, K., Harris, H., Heidari, M., 1974. Hydrogeological studies in the dry valleys. Antarct. J. US 9, 131-133.

Decker, E.R., Bucher, G.J., 1977. Geothermal studies in Antarctica. Antarct. J. US 12, 103-140.

Francelino, M.R., Schaefer, C.E.G.R., Simas, F.N.B., Fernandes Filho, E.I., Souza, J.J.L.L., Costa, L.M., 2011. Geomorphology and soils distribution under periglacial conditions in an ice-free area of Admiralty Bay, King George Island, Antarctica. Catena 85, 194-204.

Guglielmin, M., 2006. Ground surface temperature (GST), active layer, and permafrost monitoring in continental Antarctica. Permafr. Periglac. Process. 17, 133-143.

Guglielmin, M., Evans, C.J.E., Cannone, N., 2008. Active layer thermal regime under different vegetation conditions in permafrost areas, a case study at Signy Island (Maritime Antarctica). Geoderma 144, 73-85.

Hinkel, K.M., Outcalt, S.I., Nelson, F.E., 1990. Temperature variation and apparent thermal diffusivity in the refreezing active layer, Toolik Lake, Alaska. Permafr. Periglac. Process. 14, 265-274.

Hinkel, K.M., Paetzold, F., Nelson, F.E., Bockheim, J.G., 2001. Patterns of soil temperature and moisture in the active layer and upper permafrost at barrow, Alaska: $1993-$ 1999. Glob. Planet. Chang. 29, 293-309.
Hrbáček, F., Kamil, L., Zbyněk, E., 2015. Effect of snow cover on the active-layer thermal regime - a case study from James Ross Island, Antarctic Peninsula. Permafr. Periglac. Process.

Ikard, S.J., Gooseff, M.N., Barrett, J.E., Takacs-Vesbach, C., 2009. Thermal characterisation of active layer across a soil moisture gradient in the McMurdo Dry Valleys, Antarctica. Permafr. Periglac. Process. 20, 27-39.

Kane, D.L., Hinkel, K.M., Goering, D.J., Hinzman, L.D., Outcalt, S.I., 2001. Non-conductive heat transfer associated with frozen soils. Glob. Planet. Chang. 29, 275-292.

Mcgaw, R.W., Outcalt, S.I., Ng, E., 1978. Thermal properties and regime of wet tundra soils at Barrow, Alaska. Third International Conference on Permafrost, National Research Council of Canada, Ottawa, Canada, pp. 47-53.

McKay, C.P., Mellon, M.T., Friedmann, E.I., 1998. Soil temperatures and stability of icecemented ground in the McMurdo Dry Valleys, Antarctica. Antarct. Sci. 10, 31-38.

Michel, R.F.M., Schaefer, C.E.G.R., López-Martínez, J., Simas, F.N.B., Haus, N.W., Serrano, E., Bockheim, J.G., 2014. Soils and landforms from Fildes Peninsula and Ardley Island, Maritime Antarctica. Geomorphology 225, 76-86.

Nelson, F.E., Outcalt, S.I., Goodwin, C.W., Hinkel, K.M., 1985. Diurnal thermal regime in a peat-covered palsa, Toolik Lake, Alaska. Arctic 38, 310-315.

Outcalt, S.I., Hinkel, K.M., 1989. Night frost modulation of near surface soil-water ion concentration and thermal fields. Phys. Geogr. 10, 336-346.

Øvstedal, D.O., Schaefer, C.E.G.R., 2013. A new lichen species from the Heritage Range, Ellsworth Mountains, Antarctica. Hoehnea 40 (2), 361-364.

Pringle, D.J., Dickinson, W.W., Trodahl, H.J., Pyne, A.R., 2003. Depth and seasonal variations in the thermal properties of Antarctic Dry Valley permafrost from temperature time series analysis. J. Geophys. Res. 108, 2474.

Rosa, K.K., Vieira, R., Simões, J.C., 2013. Identificação de Mudanças Ambientais Através da Caracterização Sedimentar e Investigação de Processos Glaciogênicos e Paraglaciais no Ambiente glacial da Geleira Wanda, Ilha Rei George, Antártica. Rev. Bras. Geogr. Fís. 6 (1), 29-36.

Ugolini, F.C., 1964. Soil investigations in the lower Wright Valley, Antarctica. Proceedings of the First International Permafrost Conference. National Academy of Sciences, National Research Council. Publication 1287, pp. 55-61.

Ugolini, F.C., Bull, C., 1965. Soil development and glacial events in Antarctica. Quaternaria 7, 251-269.

Vieira, R., Simões, J.C., 2011. Geomorfologia glacial dos Montes patriot e Montes independence, Montanhas Ellsworth, Manto de Gelo da Antártica Ocidental. Rev. Bras. Geomorfologia 12 (1), 45-58.

Vieira, G., Bockheim, J., Guglielmin, M., Balks, M., Andrey, A., Boelhouwers, J., Cannone, N., Ganzer, L., Gilchinsky, D., Goryachkin, S., López-Martínez, J., Meiklejohn, I., Raffi, R., Ramos, M., Schaefer, C., Serrano, E., Simas, F., Sletten, R., Wagner, D., 2010. Thermal state of Antarctic permafrost and active-layer dynamics: advances during the international polar year 2007-2008. Permafr. Periglac. Process. 21, 182-197.

Vieira, R., Hinata, S., Rosa, K.K., Zilberstein, S., Simões, J.C., 2012. Periglacial features in Patriot Hills, Ellsworth Mountains, Antarctica. Geomorfology 155-159, 96-101.

Webers, G.F., Craddock, C., Splettstoesser, J.F., 1992. Geological history of the Ellsworth Mountains, West Antarctica. In: Webers, G.F., Craddock, C., Splettstoesser, J.F. (Eds.), Geology and Paleontology of the Ellsworth Mountains, West AntarcticaMemoir 170. Geological Society of America, Boulder, pp. 181-248. 